\title{
Influence of age, comorbidity and performance status on the choice of treatment for patients with non-small cell lung cancer; results of a population-based study
}

Citation for published version (APA):

de Rijke, J. M., Schouten, L. J., ten Velde, G. P. M., Wanders, S. L., Bollen, E. C., Lalisang, R. I., Dijck, J. A. A. M., Kramer, G. W., \& van den Brandt, P. A. (2004). Influence of age, comorbidity and performance status on the choice of treatment for patients with non-small cell lung cancer; results of a populationbased study. Lung Cancer, 46(2), 233-45. https://doi.org/10.1016/j.lungcan.2004.03.011

Document status and date:

Published: 01/01/2004

DOI:

10.1016/j.lungcan.2004.03.011

Document Version:

Publisher's PDF, also known as Version of record

Please check the document version of this publication:

- A submitted manuscript is the version of the article upon submission and before peer-review. There can be important differences between the submitted version and the official published version of record.

People interested in the research are advised to contact the author for the final version of the publication, or visit the DOI to the publisher's website.

- The final author version and the galley proof are versions of the publication after peer review.

- The final published version features the final layout of the paper including the volume, issue and page numbers.

Link to publication

\footnotetext{
General rights rights.

- You may freely distribute the URL identifying the publication in the public portal. please follow below link for the End User Agreement:

www.umlib.nl/taverne-license

Take down policy

If you believe that this document breaches copyright please contact us at:

repository@maastrichtuniversity.nl

providing details and we will investigate your claim.
}

Copyright and moral rights for the publications made accessible in the public portal are retained by the authors and/or other copyright owners and it is a condition of accessing publications that users recognise and abide by the legal requirements associated with these

- Users may download and print one copy of any publication from the public portal for the purpose of private study or research.

- You may not further distribute the material or use it for any profit-making activity or commercial gain

If the publication is distributed under the terms of Article $25 \mathrm{fa}$ of the Dutch Copyright Act, indicated by the "Taverne" license above, 


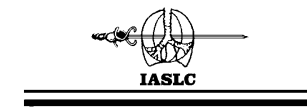

\title{
Influence of age, comorbidity and performance status on the choice of treatment for patients with non-small cell lung cancer; results of a population-based study
}

\author{
J.M. de Rijke ${ }^{a, *}$, L.J. Schouten ${ }^{a, b}$, G.P.M. ten Velde ${ }^{c}$, S.L. Wanders ${ }^{d}$, \\ E.C.M. Bollen ${ }^{\mathrm{e}}$, R.I. Lalisang ${ }^{f}$, J.A.A.M. van Dijck ${ }^{g}$, G.W.P. Kramer ${ }^{\text {h }}$, \\ P.A. van den Brandt ${ }^{b}$
}

a Department of Cancer Registration and Epidemiology, Comprehensive Cancer Centre Limburg, PO 2208, 6201 HA Maastricht, the Netherlands

${ }^{\mathrm{b}}$ Department of Epidemiology, NUTRIM, Maastricht, the Netherlands

c Department of Pulmonology, University Hospital Maastricht, Maastricht, the Netherlands

${ }^{\mathrm{d}}$ Radiotherapy Institute Limburg, Heerlen, the Netherlands

e Department of Surgery, Atrium Medical Centre, Heerlen, the Netherlands

f Department of Internal Medicine, University Hospital Maastricht, Maastricht, the Netherlands

g Datacentre, Comprehensive Cancer Centre East, Nijmegen, the Netherlands

${ }^{\mathrm{h}}$ RADIAN Joint Centre of Oncology Arnhem/Nijmegen, Location ARTI, the Netherlands

Received 16 December 2003; received in revised form 24 March 2004; accepted 29 March 2004

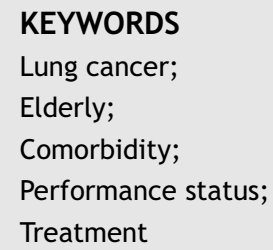

\begin{abstract}
Summary
Background: In the Netherlands in 1997, 43\% of patients with newly diagnosed lung cancer were over 70. Large age-specific differences in treatment exist. We examined whether age, comorbidity, performance status and pulmonary function influenced treatment.

Patients and methods: Data on patients with newly diagnosed non-small cell lung cancer $(N=803)$ were obtained: comorbidity, performance status, pulmonary function (FEV1) and initial treatment. Age-specific differences in treatment according to the guidelines were examined. Odds ratios were calculated by means of logistic regression analyses.

Results: $82 \%$ with stage I or II disease received treatment according to the guidelines; this applied to $48 \%$ with stage IIIA disease and to $54 \%$ with stage IIIB disease. For all stages, this proportion decreased with increasing age. In stage IV disease, 36\% did not receive any treatment; this applied to $52 \%$ of the elderly patients $\left(75^{+}\right.$years $)$. Multivariate analyses showed associations between comorbidity and treatment choice, but none with performance status. Age of $75^{+}$years appeared to be the most important factor for not receiving treatment according to guidelines.
\end{abstract}


Conclusion: A substantial proportion of elderly patients with non-small cell lung cancer did not receive standard treatment. Performance status and comorbidity seldom formed the underlying reason. Calendar rather than biological age seemed to play the most important role in choice of treatment for patients with non-small cell lung cancer.

(c) 2004 Elsevier Ireland Ltd. All rights reserved.

\section{Introduction}

Lung cancer is a major health problem in the Netherlands, as it is in almost every Western country. Forty-three per cent of patients with newly diagnosed lung cancer are older than 70 years [1]. A previous study showed that more elderly patients with various forms of cancer often did not receive any treatment or received less extensive treatment than their younger counterparts [2].

Large age-specific differences in the diagnostic procedure and treatment methods were especially found in non-small cell lung cancer.

The presence of concurrent health conditions, also known as comorbidities, is seen as one of the most important reasons not to apply the standard therapy. Without comorbidity adjustment, it can be argued that any apparent age bias in decision making is only a reflection of the poorer general health of older patients. In earlier studies, effects were found even after adjusting for comorbidity [3] or performance status [4]. This strongly suggests that physicians are basing their decisions on calendar age rather than on biological age. Population-based studies on age-specific treatment differences in non-small cell lung cancer patients are scarce and very few have addressed several important prognostic factors, such as comorbidity, performance status and pulmonary function in association with the actual treatment received [5]. In the present study, elaborate treatment data (e.g. dose of radiation received) were retrieved from the medical files. While taking into account the regional treatment guidelines, we analysed the influence of age, comorbidity, performance status and pulmonary function on the choice of treatment for non-small cell lung cancer patients.

\section{Patients and methods}

\subsection{Study population}

Data on patients with newly diagnosed non-small cell lung cancer were provided by two regional cancer registries: the cancer registry department of the Comprehensive Cancer Centre East (IKO) for the period 1 January-1 June $1998(N=283)$ and the
Maastricht Cancer Registry, department of the Comprehensive Cancer Centre Limburg (IKL) for the period 1 May 1997-1 May $1998(N=520)$. The total area represented a population of around 2.1 million in 1997. All cases not confirmed to be small cell tumours were considered as being non-small cell lung cancer, including those without histological/cytological confirmation. This means that in some cases the stage could not be defined (stage not applicable).

As this study addressed determinants of treatment choice in a non-selected population, we also included patients whose lung cancer was not their first primary malignancy ( $15 \%$ of the total study group). Registration clerks actively collected data on all the patients from the medical records. In addition to the standard cancer registry items on diagnosis, stage and initial treatment, extensive treatment data were documented, such as the total dose of radiotherapy received, comorbidity, performance status and pulmonary function (forced expiratory volume in $1 \mathrm{~s}$ (FEV1)).

Data on comorbidity and performance status were extracted from previous hospital admissions, letters of referral or discharge to general practitioners, the medical history, current medication and preoperative assessments. Comorbidity was recorded using a slightly adapted list of serious diseases developed by Charlson et al. (see Appendix A) [6]. Having an earlier malignancy also forms part of the Charlson comorbidity index.

Different rating systems are used in oncology to assess performance status, i.e. a patient's functional capacity to work and perform daily activities: the Karnofsky scale [7], the scale described by Zubrod et al. [8] which has been adapted by the Eastern Oncology Group (ECOG) and the World Health Organisation (WHO). The registration clerks recorded all the rating systems used by the specialists; for the analyses, the different scales were translated into the WHO scale (see Appendix B). Although performance status is recognised as being an important prognostic factor in patients with lung cancer [9] this item is not well-documented by physicians. Therefore the registration clerks had to estimate a patient's performance status on the basis of medical history reports written in the medical files by physicians and nurses. 
In lung cancer patients, pulmonary function assessment forms part of the standard diagnostic procedure. To estimate the influence of this item, the forced expiratory volume in $1 \mathrm{~s}$ (FEV1) and the diffusion capacity for carbon monoxide (DLCO) were recorded. In the analyses, only the FEV1 was used, however, because DLCO was missing in the majority (54\%) of cases.

Clinical stage is recorded by the registries according to the current TNM classification system. A new edition of the TNM classification was published in 1997 and became widely available in 1998 [10]. In the present study, however, the 1987 edition [11] with adaptations from 1992 [12] was used, because the prevailing regional treatment guidelines for non-small cell lung cancer, published in 1997 [13] were based on the 1992 TNM classification. The subsequent changes in the TNM classification have already been mentioned. The most important adaptation was that a T3 tumour without positive lymph nodes (NO) was classified as stage IIIA, while in the new version, this is stage IIB.

Patients staged as $C M x$ were not considered to have distant metastases ( $\mathrm{CMO}$ ), provided that $\mathrm{T}$ and $\mathrm{N}$ were known.

Guidelines valid in the IKL region [13] dated back to April 1997, while those in the IKO region were from 1988 [14]. The guidelines in the two regions were compatible, although those in the IKL region were more specific. The latter definitions were used in our analyses, in order to make differences and variations more visible and concrete.

On the basis of detailed information on the treatment received in the first 3 months after diagnosis, we examined whether patients had been treated in accordance with the guidelines (stages I + II, IIIA,
IIIB). Treatment definitions per stage according to the guidelines are given in Table 1. For stage IV, we examined which patients received palliative treatment and which patients did not.

\subsection{Analyses}

Adjusted and unadjusted odds ratios for whether or not treatment had been received according to the guidelines were calculated by means of logistic regression analyses (SAS, procedure LOGIST). As treatment guidelines are defined by stage of disease, subgroup analyses were performed for patients with stages I and II, stage IIIA and stage IIIB, and stage IV. Variables included in the models (backwards, $\alpha 0.05)$ were age (0-59 years (reference category (ref)), 60-74 years, $75^{+}$years), sex, comorbidity (no concomitant disease (ref), 1-2 concomitant diseases, 3 or more concomitant diseases), performance status ( 0 (ref), 1-2, 3-4, unknown), FEV1 ( $<2.5 \mathrm{~L}$ (ref), $>2.5 \mathrm{~L}$, unknown) and Cancer Registry (IKO/IKL). For stage IIIA, a variable for T3NO tumour (no positive lymph nodes) was included (yes/no), because of the changes in TNM versions.

Initially, "having an earlier malignancy" (yes/no), was also included in the multivariate model. Because no independent influence on the outcome variable (treated according to the guidelines yes/no) was found this variable was not included in the final model which is presented in the results.

\section{Results}

The total study population comprised 803 patients with non-small cell lung cancer. Eighty per cent of

Table 1 Definitions of treatment according to the guidelines by stage

\begin{tabular}{|c|c|c|}
\hline TNM stage & Intention & Treatment according to the guidelines \\
\hline Stages I and II (T1-2 N0-1 M0) & Curative & $\begin{array}{l}\text { Surgery, including local excision, lobectomy and } \\
\text { pneumectomy } \\
\text { Radiotherapy (RT) } 60 \mathrm{~Gy} \text { ( } 2 \text { Gy fractions) or } 51 \mathrm{~Gy} \\
\text { (3 Gy fractions) }\end{array}$ \\
\hline $\begin{array}{c}\text { Stage III A (T1-2 N2 } \\
\text { MO, T3 NO-2 MO) }\end{array}$ & Long locoregional control & $\begin{array}{l}\text { Surgery } \pm \text { RT } \\
\text { Radiotherapy } 60 \mathrm{~Gy} \text { ( } 2 \text { Gy fractions) or } 55 \mathrm{~Gy} \\
(2.5 \mathrm{~Gy} \text { fractions }) \pm \text { chemotherapy }\end{array}$ \\
\hline $\begin{array}{r}\text { Stage IIIB (any T N3 } \\
\text { M0; T4 any N MO) }\end{array}$ & $\begin{array}{l}\text { Locoregional control } \\
\text { Palliation }\end{array}$ & $\begin{array}{l}\text { Surgery } \pm \text { RT } \\
\text { Radiotherapy } 50 \text { Gy ( } 2 \text { Gy fractions) or } 40 \text { Gy }(2.5 \\
\text { fractions) } \pm \text { chemotherapy } \\
\text { Radiotherapy } 40-49 \text { Gy ( } 2 \text { Gy fractions) or } \\
30-39 \text { Gy ( } 3 \text { Gy fractions) }\end{array}$ \\
\hline Stage IV (any T any N M1) & Palliation & Radiotherapy \\
\hline
\end{tabular}


Table 2 Patient characteristics NSCLC (1997-1998) stratified by age group

\begin{tabular}{|c|c|c|c|c|}
\hline & \multicolumn{4}{|l|}{ Age (year) } \\
\hline & $\leq 59, N(\%)$ & $60-74, N(\%)$ & $75^{+}, N(\%)$ & Total, $N(\%)$ \\
\hline \multicolumn{5}{|l|}{ Sex } \\
\hline Women & $69(39)$ & $73(18)$ & $23(11)$ & $165(20)$ \\
\hline Men & $107(61)$ & $338(82)$ & $193(89)$ & $638(80)$ \\
\hline \multicolumn{5}{|l|}{ Stage } \\
\hline 1 & $35(20)$ & $111(27)$ & $57(26)$ & $203(25)$ \\
\hline II & $4(2)$ & $3(1)$ & $3(1)$ & $10(1)$ \\
\hline IIIA & $32(18)$ & $67(16)$ & $31(14)$ & $130(16)$ \\
\hline IIIB & $35(20)$ & $72(18)$ & $40(19)$ & $147(18)$ \\
\hline IV & $61(35)$ & $113(27)$ & $50(23)$ & $224(28)$ \\
\hline$X, N A^{a}$ & $9(5)$ & $45(11)$ & $35(16)$ & $89(11)$ \\
\hline \multicolumn{5}{|l|}{ Histology } \\
\hline Large cell carcinoma & $48(27)$ & $77(19)$ & $35(16)$ & $160(20)$ \\
\hline Squamous cell carcinoma & $51(29)$ & $168(41)$ & $100(46)$ & $319(40)$ \\
\hline Adenocarcinoma & $62(35)$ & $110(27)$ & $36(17)$ & $208(26)$ \\
\hline Other ${ }^{\mathrm{b}}$ & $11(6)$ & 27 (7) & 19 (9) & 57 (7) \\
\hline No histological verification & $4(2)$ & $29(7)$ & $26(12)$ & 59 (7) \\
\hline \multicolumn{5}{|l|}{ Comorbidity (no) } \\
\hline 0 & $106(60)$ & $99(24)$ & $43(20)$ & $248(31)$ \\
\hline 1 & $38(22)$ & $152(37)$ & $73(34)$ & $263(33)$ \\
\hline 2 & $16(9)$ & $86(21)$ & $48(22)$ & 150 (19) \\
\hline$\geq 3$ & $4(2)$ & $54(13)$ & $42(19)$ & $100(12)$ \\
\hline Unknown & $12(7)$ & $20(5)$ & $10(5)$ & $42(5)$ \\
\hline \multicolumn{5}{|l|}{ Performance status } \\
\hline 0 & $99(56)$ & $181(44)$ & $79(37)$ & $359(45)$ \\
\hline 1 & $20(11)$ & 80 (19) & $53(24)$ & $153(19)$ \\
\hline 2 & $14(8)$ & 30 (7) & $19(9)$ & $63(8)$ \\
\hline 3 & $5(3)$ & $13(3)$ & $6(3)$ & $24(3)$ \\
\hline 4 & $2(1)$ & $5(1)$ & $3(1)$ & $10(1)$ \\
\hline Unknown & $36(20)$ & $102(25)$ & $56(26)$ & $194(24)$ \\
\hline \multicolumn{5}{|l|}{ Region } \\
\hline IKL & $112(64)$ & $267(65)$ & $141(65)$ & $520(65)$ \\
\hline IKO & $64(36)$ & $144(35)$ & $75(35)$ & $283(35)$ \\
\hline Total & $176(100)$ & $411(100)$ & $216(100)$ & $803(100)$ \\
\hline
\end{tabular}

${ }^{a} X$, unknown $(N=27)$; NA, not applicable $((N=62)$ (no histology $N=59$; tumour cells not otherwise specified (NOS) $N=3)$ ).

${ }^{b}$ Other: tumour cells NOS $(N=3)$; carcinoma NOS $(N=32)$; carcinoma undifferentiated NOS $(N=3)$; pseudosarcomatous carcinoma $(N=1)$; carcinoid $\operatorname{NOS}(N=6)$; neuroendocrine carcinoma $(N=6)$; adenosquamous carcinoma $(N=6)$.

the patients were male and $20 \%$ were female; $51 \%$ were aged between 60 and 74 years and $27 \%$ were aged 75 years or older. Table 2 shows some relevant patient characteristics stratified by age group. Proportions of stage IV decreased with increasing age, while proportions of stage unknown or not applicable increased with increasing age.

The proportion of patients with one or more comorbidities increased with increasing age and the proportion of patients with a good performance status was lower among the elderly patients.

\subsection{Stages I and II}

In the patients with stage I or II disease, $82 \%$ received treatment according to the guidelines, i.e. surgery or radiotherapy (Tables 1 and 4). However, the proportions decreased with increasing age, from $97 \%$ in the age group 59 years and younger, to $86 \%$ in the age group $60-74$ years and to $65 \%$ in the age group 75 years and older.

Surgical procedures $(N=142)$ were lobectomy $(64 \%)$, pneumectomy $(31 \%)$ and smaller resections 
Table 3 Adjusted and unadjusted Odds Ratios (OR) with 95\% confidence interval in parentheses for treatment of NSCLC not according to the guidelines (stages I and II, IIIA, IIIB) and for no treatment (stage IV)

\begin{tabular}{|c|c|c|c|c|c|c|c|c|}
\hline & \multicolumn{2}{|l|}{ Stages I and II } & \multicolumn{2}{|l|}{ Stage IIIA } & \multicolumn{2}{|l|}{ Stage IIIB } & \multicolumn{2}{|l|}{ Stage IV } \\
\hline & Unadjusted OR & Adjusted OR & Unadjusted OR & Adjusted OR & Unadjusted OR & Adjusted OR & Unadjusted OR & Adjusted OR \\
\hline \multicolumn{9}{|l|}{ Age (year) } \\
\hline$\leq 59$ & 1 (ref) & 1 (ref) & 1 (ref) & 1 (ref) & 1 (ref) & 1 (ref) & 1 (ref) & 1 (ref) \\
\hline$\overline{60}-74$ & $3.2(0.9-11)$ & $2.2(0.6-8.1)$ & $1.3(0.6-3.0)$ & $1.2(0.4-3.4)$ & $1.1(0.5-2.5)$ & $0.8(0.3-2.1)$ & $2.1(1.0-4.4)$ & $2.1(0.9-5.0)$ \\
\hline $75^{+}$years & $12.8(3.5-46)$ & $8.5(2.2-32)$ & $3.6(1.2-10)$ & $3.9(1.1-14)$ & $3.5(1.3-9.1)$ & $2.2(0.7-6.8)$ & $4.7(2.0-11)$ & $5.1(2.0-13)$ \\
\hline \multicolumn{9}{|c|}{ Pulmonary function (FEV1) } \\
\hline$<2.5 \mathrm{~L}$ & $1.5(0.7-3.1)$ & $1.0(0.5-2.3)$ & $1.1(0.5-2.3)$ & $0.9(0.3-2.6)$ & $2.8(1.1-7.1)$ & $2.3(0.8-6.2)$ & $4.2(1.4-13)$ & $3.9(1.2-12)$ \\
\hline$\geq 2.5 \mathrm{~L}$ & 1 (ref) & 1 (ref) & 1 (ref) & 1 (ref) & 1 (ref) & 1 (ref) & 1 (ref) & 1 (ref) \\
\hline Unknown & $2.4(0.9-6.8)$ & $2.4(0.7-8.3)$ & $2.2(0.7-6.8)$ & $2.5(0.6-10)$ & $3.0(1.1-8.2)$ & $1.9(0.6-5.8)$ & $4.6(1.5-14)$ & $4.7(1.4-15)$ \\
\hline \multicolumn{9}{|l|}{ Comorbidity } \\
\hline 0 & 1 (ref) & 1 (ref) & 1 (ref) & 1 (ref) & 1 (ref) & 1 (ref) & 1 (ref) & 1 (ref) \\
\hline $1-2$ & $6.5(2.2-19)$ & $4.8(1.5-15)$ & $1.0(0.5-2.3)$ & $1.3(0.5-3.2)$ & $2.3(1.1-4.8)$ & $1.9(0.8-4.4)$ & $1.2(0.6-2.2)$ & $0.8(0.4-1.7)$ \\
\hline $3 \geq$ & $8.2(2.4-28)$ & $5.7(1.5-21)$ & $0.9(0.3-2.5)$ & $0.7(0.2-2.2)$ & $1.9(0.7-5.1)$ & $1.3(0.4-4.0)$ & $1.2(0.5-3.0)$ & $0.7(0.3-1.8)$ \\
\hline \multicolumn{9}{|c|}{ Performance status } \\
\hline 0 & 1 (ref) & 1 (ref) & 1 (ref) & 1 (ref) & 1 (ref) & 1 (ref) & 1 (ref) & 1 (ref) \\
\hline $1-2$ & $3.1(1.4-6.8)$ & $2.1(0.9-4.9)$ & $1.5(0.6-3.3)$ & $1.8(0.7-4.6)$ & $1.7(0.8-3.7)$ & $1.5(0.7-3.4)$ & $1.1(0.5-2.1)$ & $0.9(0.4-1.8)$ \\
\hline $3-4$ & - & - & $6.3(0.7-57)$ & $2.9(0.3-30)$ & $5.2(0.5-52)$ & $5.3(0.4-64)$ & $1.1(0.3-3.4)$ & $0.9(0.2-3.3)$ \\
\hline Unknown & $1.2(0.5-2.6)$ & $0.8(0.3-1.9)$ & $1.6(0.6-4.3)$ & $1.5(0.5-4.9)$ & $2.1(0.9-5.1)$ & $2.1(0.8-5.7)$ & $1.4(0.7-3.0)$ & $1.3(0.6-2.8)$ \\
\hline \multicolumn{9}{|l|}{ TNM T3NO } \\
\hline Yes & Not Applicable & & $0.1(0.0-0.4)$ & $0.08(0.0-0.3)$ & Not applicable & & Not applicable & \\
\hline No & & & 1 (ref) & 1 (ref) & & & & \\
\hline \multicolumn{9}{|c|}{ Comprehensive Cancer Centre } \\
\hline IKO & 1 (ref) & & 1 (ref) & & 1 (ref) & & 1 (ref) & \\
\hline $\mathrm{IKL}$ & $1.1(0.5-2.0)$ & a & $0.7(0.3-1.4)$ & a & $0.9(0.4-1.9)$ & a & $1.1(0.6-1.9)$ & a \\
\hline
\end{tabular}

a Variable not included in the final model. 
(5\%) (data not shown). In this group, 95\% of the patients without any serious concomitant diseases and $73 \%$ of the patients with three or more concomitant diseases were treated according to the guidelines. More patients with a good performance status (WHO grade 0 ) received treatment according to the guidelines then patients with a poorer performance status (WHO grade 1-2). In a logistic regression model, the factor age of 75 years or older was associated with higher proportions of patients who did not receive treatment according to the guidelines $(\mathrm{OR}=8.5 ; 95 \% \mathrm{Cl} 2.2-32)$. Also the presence of comorbidity appeared to significantly influence the treatment of this group of lung cancer patients (Table 3). After adjusting for the other variables, ORs for performance status were no longer significantly increased.

\subsection{Stage III A}

About $48 \%$ of the patients with stage IIIA NSCLC received treatment according to the guidelines, i.e. surgery with or without radiotherapy, radiotherapy alone or in combination with chemotherapy (Table 1 and 4). More patients aged 75 years and older had not been treated according to the guidelines $(71 \%)$ than their younger counterparts. In the univariate as well as the multivariate analyses, age was the most important risk factor for not receiving treatment according to the guidelines (Table 3 ). The presence of one or more comorbidities, or other variables such as performance status and pulmonary function did not show any significant association with not receiving treatment according to the guidelines. In patients without positive lymph nodes (T3N0) the risk of not being treated according to the guidelines was significantly lower than in the other categories of stage IIIA (OR 0.08, 95\% Cl: 0.03-0.33).

\subsection{Stage IIIB}

Fifty-four per cent of the patients with stage IIIB disease received treatment according to the guidelines, i.e. surgery, radiotherapy, a combination of the two, or RT with chemotherapy (Table 1). In patients aged 75 years and over, this proportion was lower: $33 \%$ (Table 4). The large majority (73\%) of stage IIIB patients who were treated according to the guidelines received radiotherapy alone; 29 out of these 58 patients received a palliative dose (not shown). In the univariate analysis, age of 75 years and over, pulmonary function $(\mathrm{FEV} 1<2.5 \mathrm{~L}$ or unknown) and the presence of one or two comorbidities showed a significantly higher risk for not receiving treatment according to the guidelines
(Table 3). However, in the multivariate analyses, none of these factors remained significantly associated with the risk of not being treated according to the guidelines.

\subsection{Stage I + II, IIIA, IIIB, treatment not according to the guidelines}

Table 5 shows the patients with stage I + II, IIIA and IIIB who had not been treated according to the guidelines: 37 patients with stages I and II NSCLC had not been treated according to the guidelines and 24 had not received any treatment, all of them were 60 years or older. Radiotherapy with less than a total dose of $60 \mathrm{~Gy}$ (2 Gy fractions) or $51 \mathrm{~Gy}$ ( $2.5 \mathrm{~Gy}$ fractions) had been received by 11 patients, whereas one patient had received RT in combination with chemotherapy and one patient had been treated with chemotherapy alone.

Fifty-one per cent of the stage IIIA patients did not receive treatment according to the guidelines. In this group, 28 patients had received radiotherapy alone, but a total dose of less than $60 \mathrm{~Gy}$ ( $2 \mathrm{~Gy}$ fractions) or $55 \mathrm{~Gy}$ (2.5Gy fractions); 17 patients received chemotherapy with or without another modality, but not according to the guidelines, while 21 patients $(16 \%)$ did not receive any treatment. In contrast with stage IIIA, a large proportion of the stage IIIB patients were not treated at all $(66 \%)$ and this percentage increased with increasing age. Treatment consisted of radiotherapy with a dose of less than $30 \mathrm{~Gy}(19 \%)$ or chemotherapy (13\%).

\subsection{Stage IV}

In the years 1997 and 1998 there was no clear standard treatment for stage IV NSCLC. Survival rates were low and treatment was administered for palliative purposes. Table 6 shows the proportions of patients who received treatment and those who did not. No treatment had been applied to $36 \%$ $(N=76)$ of the patients. This proportion differed by age group: $20 \%$ of the patients aged 59 years or younger had not been treated, $34 \%$ of the patients aged $60-74$ years and $52 \%$ of those aged 75 years or older. Patients who had been treated mostly received radiotherapy $(N=94)$ or chemotherapy $(N=30)$ (Table 6). Table 7 presents treatment by age and whether radiotherapy was locoregional, to metastases, or both. The proportion of patients that received radiotherapy to metastases decreased with increasing age: $43 \%$ of the patients aged 59 years or younger, $26 \%$ of the patients aged $60-74$ years and $18 \%$ of the patients aged 75 years and over. Chemotherapy was mostly administered 
Table 4 Patient characteristics stages I and II, IIIA, IIIB NSCLC and distribution of treatment (not) according to the guidelines

\begin{tabular}{|c|c|c|c|c|c|c|c|c|c|}
\hline & \multicolumn{3}{|l|}{ Stages I and II } & \multicolumn{3}{|l|}{ Stage IIIA } & \multicolumn{3}{|l|}{ Stage IIIB } \\
\hline & $\begin{array}{l}\text { Not according to } \\
\text { guidelines } N(\%)\end{array}$ & $\begin{array}{l}\text { According to } \\
\text { guidelines } N(\%)\end{array}$ & Total $N$ & $\begin{array}{l}\text { Not according to } \\
\text { guidelines } N(\%)\end{array}$ & $\begin{array}{l}\text { According to } \\
\text { guidelines } N(\%)\end{array}$ & Total N & $\begin{array}{l}\text { Not according to } \\
\text { guidelines } N(\%)\end{array}$ & $\begin{array}{l}\text { According to } \\
\text { guidelines } N(\%)\end{array}$ & Total $N$ \\
\hline \multicolumn{10}{|l|}{ Age (year) } \\
\hline$\leq 59$ & $1(3)$ & $38(97)$ & 39 & $13(41)$ & 19 (59) & 32 & $13(37)$ & $22(63)$ & 35 \\
\hline $60-74$ & $15(13)$ & $98(86)$ & $114^{\mathrm{a}}$ & $31(46)$ & $35(52)$ & $67^{\mathrm{a}}$ & $28(39)$ & $44(61)$ & 72 \\
\hline $75^{+}$ & $21(35)$ & $39(65)$ & 60 & $22(71)$ & 9 (29) & 31 & $27(67)$ & $13(33)$ & 40 \\
\hline \multicolumn{10}{|c|}{ Pulmonary function (FEV1) } \\
\hline $0.5-1.0 \mathrm{~L}$ & $3(25)$ & $9(75)$ & 12 & $5(83)$ & $1(17)$ & 6 & $4(50)$ & $4(50)$ & 8 \\
\hline $1.1-2.4 \mathrm{~L}$ & 19 (17) & $91(83)$ & 110 & $30(45)$ & $36(55)$ & 66 & $33(51)$ & $32(49)$ & 65 \\
\hline$\geq 2.5 \mathrm{~L}$ & 7 (10) & $60(90)$ & 67 & 17 (47) & $19(53)$ & 36 & $8(27)$ & $22(73)$ & 30 \\
\hline Unnknown & $8(35)$ & $15(65)$ & 23 & $14(64)$ & $7(32)$ & $22^{\mathrm{a}}$ & $23(52)$ & $21(48)$ & 44 \\
\hline \multicolumn{10}{|l|}{ Therapy } \\
\hline No therapy & $24(100)$ & - & 24 & $21(100)$ & - & 21 & $45(100)$ & - & 45 \\
\hline Surgery & - & $123(100)$ & 123 & - & $16(100)$ & 16 & - & $8(100)$ & 8 \\
\hline Radiotherapy (RT) & $11(25)$ & $33(75)$ & 44 & $28(49)$ & $29(51)$ & 57 & $13(18)$ & $58(82)$ & 71 \\
\hline Surgery + RT & - & $19(100)$ & 19 & - & $8(100)$ & 8 & - & $4(100)$ & 4 \\
\hline Chemotherapy (CT) & $1(50)$ & - & $2^{\mathrm{a}}$ & $9(100)$ & - & 9 & $9(100)$ & - & 9 \\
\hline $\mathrm{RT}+\mathrm{CT}$ & $1(100)$ & - & & $2(17)$ & $10(83)$ & 12 & - & $9(100)$ & 9 \\
\hline $\mathrm{S}+\mathrm{CT} / \mathrm{S}+\mathrm{RT}+\mathrm{CT}$ & - & - & & $6(100)$ & - & 6 & $1(100)$ & - & 1 \\
\hline \multicolumn{10}{|l|}{ Comorbidity (number) } \\
\hline 0 & $2(3)$ & $54(95)$ & $57^{a}$ & $21(51)$ & $20(49)$ & 41 & $18(34)$ & $35(66)$ & 53 \\
\hline 1 & $13(18)$ & $60(82)$ & 73 & $25(54)$ & $21(46)$ & 46 & $26(59)$ & $18(41)$ & 44 \\
\hline 2 & $11(23)$ & $36(77)$ & 47 & $6(43)$ & $8(57)$ & 14 & $12(46)$ & $14(54)$ & 26 \\
\hline$\geq 3$ & $8(27)$ & $22(73)$ & 30 & $10(50)$ & $9(45)$ & $20^{\mathrm{a}}$ & $8(42)$ & $11(58)$ & 19 \\
\hline Ünknown & $3(50)$ & $3(50)$ & 6 & $4(44)$ & $5(56)$ & 9 & $4(80)$ & $1(20)$ & 5 \\
\hline \multicolumn{10}{|l|}{ Performance status } \\
\hline 0 & $16(12)$ & $110(87)$ & $127^{a}$ & $27(45)$ & $34(55)$ & $62^{\mathrm{a}}$ & $22(37)$ & $38(63)$ & 60 \\
\hline 1 & $5(16)$ & $26(84)$ & 31 & $16(50)$ & $16(50)$ & 32 & $20(56)$ & $16(44)$ & 36 \\
\hline 2 & $3(60)$ & $2(40)$ & 5 & $5(71)$ & $2(29)$ & 7 & $6(37)$ & $10(63)$ & 16 \\
\hline $3-4$ & - & - & - & $5(83)$ & $1(17)$ & 6 & $3(75)$ & $1(25)$ & 4 \\
\hline Unknown & $13(26)$ & $37(74)$ & 50 & $13(56)$ & $10(44)$ & 23 & 17 (55) & $14(45)$ & 31 \\
\hline \multicolumn{10}{|c|}{ Comprehensive Cancer Centre } \\
\hline $\mathrm{IKL}$ & $24(16)$ & $124(83)$ & $149^{a}$ & $41(54)$ & $34(45)$ & $76^{\mathrm{a}}$ & $42(47)$ & $48(53)$ & 90 \\
\hline IKO & $13(20)$ & $51(80)$ & 64 & $25(46)$ & $29(54)$ & 54 & $26(46)$ & $31(54)$ & 57 \\
\hline Total & 37 (17) & $175(82)$ & $213(100)$ & $66(51)$ & $63(48)$ & $130(100)$ & $68(46)$ & $79(54)$ & 147 \\
\hline
\end{tabular}

a Treatment of one patient was unknown. 
Table 5 Patients with NSCLC not treated according to the guidelines (stages I and II, IIIA, IIIB)

\begin{tabular}{|c|c|c|c|c|}
\hline & \multicolumn{4}{|l|}{ Age (year) } \\
\hline & $\leq 59, N(\%)$ & $60-74, N(\%)$ & $75^{+}, N(\%)$ & Total, $N(\%)$ \\
\hline \multicolumn{5}{|l|}{ Stages I and II } \\
\hline No therapy & - & $9(60)$ & $15(71)$ & $24(65)$ \\
\hline $\begin{array}{c}\mathrm{RT}<60 \mathrm{~Gy} \text { (2 Gy fractions) or }< \\
51 \mathrm{~Gy} \text { (3 Gy fractions) }\end{array}$ & $1(100)$ & $4(27)$ & $6(29)$ & $11(30)$ \\
\hline $\mathrm{CT} / \mathrm{RT}+\mathrm{CT}$ & - & $2(13)$ & - & $2(5)$ \\
\hline Subtotal & $1(100)$ & $15(100)$ & $21(100)$ & $37(100)$ \\
\hline \multicolumn{5}{|l|}{ Stage III A } \\
\hline No therapy & $4(31)$ & $5(16)$ & $12(55)$ & $21(16)$ \\
\hline $\begin{array}{c}\text { RT }<60 \text { Gy (2 Gy fractions) or } \\
<55 \text { Gy (2.5 Gy fractions) }\end{array}$ & $2(15)$ & $17(55)$ & $9(41)$ & $28(42)$ \\
\hline Chemotherapy (CT) & $2(15)$ & $6(19)$ & $1(4)$ & $9(14)$ \\
\hline Surgery $(\mathrm{S})+\mathrm{CT}$ & $2(15)$ & $2(6)$ & - & $4(6)$ \\
\hline Radiotherapy $(\mathrm{RT})+\mathrm{CT}$ & $2(15)$ & - & - & $2(3)$ \\
\hline $\mathrm{S}+\mathrm{RT}+\mathrm{CT}$ & $1(8)$ & $1(3)$ & - & $2(3)$ \\
\hline Subtotal & $13(100)$ & $31(100)$ & $22(100)$ & $66(100)$ \\
\hline \multicolumn{5}{|l|}{ Stage IIIB } \\
\hline No therapy & $6(46)$ & $16(57)$ & $23(85)$ & $45(66)$ \\
\hline Radiotherapy < 30 Gy & $1(8)$ & $9(32)$ & $3(11)$ & 13 (19) \\
\hline Chemotherapy & $6(46)$ & $2(7)$ & $1(4)$ & $9(13)$ \\
\hline $\mathrm{S}+\mathrm{RT}+\mathrm{CT}$ & - & $1(4)$ & - & $1(2)$ \\
\hline Subtotal & $13(100)$ & $28(100)$ & $27(100)$ & $68(100)$ \\
\hline
\end{tabular}

to younger patients and consisted of regimens with gemcitabine.

Logistic regression analysis for whether or not treatment had been received revealed that an age of 75 years or older and an FEV1 of lower than $2.5 \mathrm{~L}$ or FEV1 unknown was related to not receiving treatment.

\subsection{Stage unknown/not applicable}

Twenty-seven patients had stage unknown because of an incomplete diagnostic procedure and in 62 patients there was no histological classification, which means that their stage could not be defined. In this group, 80 out of the 89 patients were aged 60 years and older. The majority (54\%) had not received treatment and this proportion increased with increasing age: $33 \%$ of the patients aged 59 years and younger, $49 \%$ of the patients aged $60-74$ years and $66 \%$ of those aged 75 years and over. In the total group who received treatment $(N=41)$, $15 \%$ underwent surgery and $25 \%$ received radiotherapy (results not shown).

Logistic regression analyses (results not shown) indicated that the factors age 75 years or older (OR 2.9; 95\% $\mathrm{Cl}: 1.3-6.6)$, performance status of WHO 3-4 (OR 2.4; 95\% Cl:1.0-6.0) or unknown pulmonary function (OR 3.4; 95\% $\mathrm{Cl}: 1.5-7.3$ ) were associated with stage unknown or the absence of histological classification.

\section{Discussion}

The present retrospective study investigated treatment patterns for non-small cell lung cancer patients in the eastern and southern part of the Netherlands. Less than half the patients with a stage I, II, IIIA or IIIB disease (44\%) were treated according to the guidelines. Adherence to treatment guidelines was highest in stages I and II and decreased with increasing age. The majority of patients with stage IV disease received palliative treatment (63\%), but the proportions varied by age group: $79 \%$ in the age group 59 years and younger, $64 \%$ in the age group $60-74$ years and $44 \%$ in the age group 75 years and over.

After adjustment for the effect of age and cancer stage, the influences of comorbidity and performance status on treatment choice were less than expected. In the univariate analyses, significant associations with comorbidity and performance status were only found for the localised stages. Poor pulmonary function (FEV1) was associated with not 
Table 6 Patient characteristics stage IV NSCLC, treatment or no treatment

\begin{tabular}{|c|c|c|c|c|}
\hline & \multicolumn{4}{|l|}{ Stage IV } \\
\hline & No treatment & Treatment & Treatment unknown & Total \\
\hline \multicolumn{5}{|l|}{ Age } \\
\hline$\leq 59$ years & $12(20)$ & $48(79)$ & $1(2)$ & 61 \\
\hline $60-74$ years & $38(34)$ & $72(64)$ & $3(3)$ & 113 \\
\hline $75^{+}$years & $26(52)$ & $22(44)$ & $2(4)$ & 50 \\
\hline \multicolumn{5}{|c|}{ Pulmonary function (FEV1) } \\
\hline $0.5-1.0 \mathrm{~L}$ & $3(43)$ & $4(57)$ & - & 7 \\
\hline $1.1-2.4 \mathrm{~L}$ & $32(36)$ & $54(61)$ & $3(3)$ & 89 \\
\hline$\geq 2.5 \mathrm{~L}$ & 4 (12) & $28(85)$ & 1 (3) & 33 \\
\hline Unknown & $37(39)$ & $56(59)$ & $2(2)$ & 95 \\
\hline \multicolumn{5}{|l|}{ Therapy } \\
\hline No therapy & $76(100)$ & - & - & 76 \\
\hline Surgery & - & $4(100)$ & - & 4 \\
\hline Radiotherapy (RT) & - & $94(100)$ & - & 94 \\
\hline Surgery + RT & - & $3(100)$ & - & 3 \\
\hline Chemotherapy (CT) & - & $30(100)$ & - & 30 \\
\hline $\mathrm{RT}+\mathrm{CT}$ & - & $11(100)$ & - & 11 \\
\hline Unknown & - & - & $6(100)$ & 6 \\
\hline \multicolumn{5}{|l|}{ Comorbidity (no) } \\
\hline 0 & $25(32)$ & $53(67)$ & $1(1)$ & 76 \\
\hline 1 & $26(37)$ & $44(63)$ & - & 70 \\
\hline 2 & $14(33)$ & $26(62)$ & $2(5)$ & 42 \\
\hline $3 \geq$ & $6(33)$ & $11(61)$ & $1(6)$ & 18 \\
\hline Unknown & $5(33)$ & $8(53)$ & $2(14)$ & 15 \\
\hline \multicolumn{5}{|l|}{ Performance status } \\
\hline 0 & $26(32)$ & $55(68)$ & - & 82 \\
\hline 1 & $12(29)$ & $29(71)$ & - & 40 \\
\hline 2 & $11(41)$ & $16(59)$ & - & 27 \\
\hline $3-4$ & $5(33)$ & $10(67)$ & - & 15 \\
\hline Unknown & $22(37)$ & $32(53)$ & $6(10)$ & 59 \\
\hline \multicolumn{5}{|c|}{ Comprehensive Cancer Centre } \\
\hline IKL & $47(33)$ & $90(64)$ & $4(3)$ & 141 \\
\hline IKO & $29(35)$ & $52(63)$ & $2(2)$ & 83 \\
\hline Total & $76(34)$ & $142(63)$ & $6(3)$ & $224(100)$ \\
\hline
\end{tabular}

receiving palliative treatment in stage IV patients, even after adjustment for age, comorbidity and performance status.

Several factors should be considered when interpreting these findings. First, comorbidity data, performance status and pulmonary function (FEV1) were not part of the standard registration items at the time of data collection (comorbidity was included in 1999). This means that registration clerks were not used to documenting these items. To record comorbidity, methods introduced by the adjacent cancer registry in Eindhoven (IKZ) were used. They have been recording comorbidity since 1993 and a validation project has been carried out [3]. To evaluate the data on comorbidity in the present study, the prevalence of comorbidity in lung cancer patients was compared to the outcomes of the IKZ study [3]. Differences were in a range of $1-6 \%$ for both men and women in seven out of eight categories.

Second, even though great effort was made, information on performance status and FEV1 was difficult to obtain from the medical files. In $14 \%$ of the cases it was clear that no FEV1 test had been performed, while in $12 \%$ of the cases the notes in the medical files were not clear about the performance of pulmonary function tests. In both categories, the performance status was coded as unknown (percentage by age group: $\leq 59$ years: 20\%, $60-74$ years: $25 \%$ and $75^{+}$years: $26 \%$ ). 
Table 7 Treatment for stage IV NSCLC by age

\begin{tabular}{|c|c|c|c|c|}
\hline \multirow[t]{2}{*}{ Treatment } & \multicolumn{4}{|l|}{ Age (Year) } \\
\hline & $\leq 59, N(\%)$ & $60-74, N(\%)$ & $75^{+}, N(\%)$ & Total, N (\%) \\
\hline No treatment & $12(20)$ & $38(34)$ & $26(52)$ & $76(34)$ \\
\hline Surgery & $1(2)$ & $3(3)$ & - & $4(2)$ \\
\hline \multicolumn{5}{|l|}{ Radiotherapy (RT) } \\
\hline locoregional & $6(10)^{\mathrm{a}}$ & $12(11)$ & $4(8)$ & $22(10)$ \\
\hline Radiotherapy metastases & $26(43)^{b}$ & $30(26)$ & $9(18)$ & $65(29)$ \\
\hline Radiotherapy both & $4(6)^{c}$ & $10(9)$ & $4(8)$ & $18(8)$ \\
\hline Chemotherapy & $11(18)$ & $15(13)$ & $4(8)$ & $30(13)$ \\
\hline Unknown & $1(1)$ & $5(4)^{d}$ & $3(6)$ & $9(4)$ \\
\hline Total & $61(27)$ & $113(50)$ & $50(22)$ & $224(100)$ \\
\hline
\end{tabular}

Comorbidity significantly influenced treatment choice for the early stage non-small cell lung cancer. This might be related to the fact that the prevalence of comorbidity in patients with a stages I and II NSCLC was higher than that in patients with more advanced lung cancer (Table 2). This phenomenon was also found by Janssen-Heijnen et al. [3], who ascribed it to screening bias, e.g. lung cancer was diagnosed at an early stage as a result of regular monitoring of other chronic diseases. This might also explain the high proportion of elderly patients with stages I and II at diagnosis, although this could be partly the result of understaging due to less extensive diagnostic procedures [2]. A higher proportion of elderly patients with stages I and II was also found earlier $[15,16]$ but not confirmed by others [17].

In the present study, stage was classified according to the 'old' TNM classification [12]. In the new TNM classification [10], cases with T3NO (no positive lymph nodes) are classified as IIB instead of IIIA. This change in TNM classification was made because apparently, these patients have better survival and should be offered treatment with curative intent.

In the present study, T3NO patients were analysed in more detail, because physicians may have been aware of the more favourable prognosis and have treated them according to the new staging classification [18]. Compared to the other stage IIIA patients, more T3NO patients had been treated according to the guidelines. A fairly large proportion of the other stage IIIA patients had received radiotherapy to a lower total dose than advised in the guidelines $(N=28)$, or they had received no treatment at all $(N=21)$; the majority of the latter patients were aged 60 years and older.
There are no curative treatment options for patients with metastasised lung cancer (stage IV). Radiotherapy administered for palliation of severe respiratory symptoms or for metastases causing severe complaints was a generally accepted treatment policy. Therefore the characteristics of the patients who received such treatment (to prolong survival or for symptomatic relief) were compared to those of the patients who did not receive any treatment. This comparison revealed different proportions by age group: $44 \%$ of the patients aged 75 years and over received some kind of palliative treatment, mostly radiotherapy, whereas this was $64 \%$ in the age group 60-74 years and 79\% in patients aged 59 years and younger. Relatively fewer elderly patients received radiotherapy for metastases.

Clinicians who managed elderly patients with lung cancer may have felt cautious about referring them for radiotherapy. In the study period 1997-1998, research specifically performed to assess the problems and benefits of radiotherapy for lung cancer in elderly patients was scarce [19]. Patterson et al. retrospectively studied 149 lung cancer patients aged 75 years and over. They concluded that palliative radiotherapy was well tolerated and the response was similar to that in younger patients. Other studies have also indicated that (radical) radiotherapy can be applied to elderly people without increased toxicity [20-23]. However, heterogeneity among individuals increases with increasing age, and more than in younger cancer patients, all therapeutic options should be considered in relation with careful evaluation of the patient (functional assessment, comorbidities, stage of disease, social situation, individual wishes 
for therapy, etc.) [24-26]. Another positive development over the past few years is that most clinical trials no longer specify upper age limits. Unfortunately the recruitment of elderly patients in trials is still low [27].

Especially in the younger age groups with advanced stage NSCLC, chemotherapy seemed to occupy a fairly important position in the treatment options; 30 patients received chemotherapy alone and 11 received both radiotherapy and chemotherapy. At time of the study, 1997-98, the role of chemotherapy in stage IV NSCLC in everyday practice was still uncertain and did not form part of the IKL or IKO treatment guidelines. However, in 1995, the results of a meta-analysis on randomised trials revealed an increase in median survival of about 6 weeks and a 10\% improvement in 1-year survival compared to patients managed with supportive care only [28]. In subsequent years it has become clear that several chemotherapy regimens could offer a small increase in 1-year survival and a delay in symptoms that cause quality of life deterioration in elderly and unfit patients [29]. These developments led to changes in the IKL treatment guideline [30] by making chemotherapy part of the standard treatment, although it is still advised to do this in trial settings.

In the present study, performance status did not seem to play a major role in treatment choice, which is in agreement with Brown et al. [4] who studied differences in treatment for 563 lung cancer patients in the UK. We found that performance status as such was often not even mentioned in medical files. Besides, the percentage of patients with a very poor performance status (3-4), was low. Only $4 \%$ had a performance status of 3-4 (proportions were higher in patients with stage IV (7\%) and stage unknown (10\%)).

Our study population included 89 patients with unknown stage, partly because of less extensive diagnostic procedures $(N=27)$ and partly because the diagnosis was not histologically confirmed $(N=62)$. The high prevalence of comorbidities and the poor performance status of these patients may indicate that the diagnostic procedure was less extensive because of comorbid conditions or low performance status which implicitly meant that patients were not considered to be candidates for standard treatment. In some cases, this may have been the result of the misunderstanding that extensive clinical staging in the elderly is not worthwhile [31]. It seems likely that from the very beginning of the diagnostic process, there was no intention to treat these patients according to the guidelines. Obviously, there will sometimes be very good reasons not to perform extensive diagnostic procedures, or not to treat a patient according to the standard guidelines (e.g. lower RT dose). From the documentation of the reasons for treatment choice, it was learned that occasionally the disease was progressing too rapidly or sometimes the treatment-related complications were considered unacceptable. Nevertheless, in the literature there are strong indications that a nihilist approach from physicians plays an important role [32] and that the number of patients who refuse treatment is very small [33].

In the present study, the calendar age of the patient was the most important factor upon which physicians based their therapy decision. Fairly large proportions of elderly patients were not treated, were undertreated or were withheld some form of treatment for palliation. Exclusion of elderly patients from former cancer trials and lack of data concerning the benefit of treatment for elderly patients with cancer may have played a role in treatment decisions.

\section{Acknowledgements}

We thank the registration clerks of the IKL and IKO for their tremendous job on collecting all the additional information and Mrs. Judith Abma-Hill for screening the English language.

\section{Appendix A. Classification of co-morbidity, according to an adapted version of the list developed by Charlson et al. [6]}

\section{COPD}

Cardiovascular disease (myocardial infarction, cardiac decompensation, angina pectoris, intermittent claudication, abdominal aneurysm)

Cerebrovascular diseases (cerebrovascular accident, hemiplegia)

Other malignancies (except for basal cell skin carcinoma)

Hypertension

Diabetes Mellitus (medically treated)

Other

Soft tissue diseases (Besnier Boeck disease (sarcoidosis), Wegener's granulomatosis, systemic lupus erythematosis (SLE)

Rheumatoid arthritis (only severe)

Kidney diseases (chronic glomerulonephritis, chronic pyelonephritis)

Bowel diseases (Crohn's disease, ulcerative colitis) 


\author{
Liver diseases (cirrhosis, hepatitis) \\ Dementia \\ Tuberculosis
}

\section{Appendix B}

\begin{tabular}{|c|c|}
\hline \multicolumn{2}{|c|}{ WHO (Zubrod) scale } \\
\hline 0 & Normal activity \\
\hline 1 & Symptoms, but nearly fully ambulatory \\
\hline 2 & $\begin{array}{l}\text { Some bed rest, but needs to be } \\
\text { in bed for less than } 50 \% \text { of } \\
\text { normal daytime }\end{array}$ \\
\hline 3 & $\begin{array}{l}\text { Needs to be in bed for more } \\
\text { than } 50 \% \text { of normal daytime }\end{array}$ \\
\hline 4 & Unable to get out of bed \\
\hline
\end{tabular}

\section{References}

[1] Visser O, Coebergh JW, Schouten LJ. Incidence of cancer in the Netherlands. V.v.I. Kankercentra, editor. Utrecht; 2001.

[2] de Rijke JM, Schouten LJ, Schouten HC, Jager JJ, Koppejan $A G$, van der Brandt PA, et al. Age-specific differences in the diagnostics and treatment of cancer patients aged 50 years and older in the province of Limburg, the Netherlands. Ann Oncol ESMO 1996;7(7):677-85.

[3] Janssen Heijnen MLG, Schipper RM, Razenberg PPA, Crommelin MA, Coebegh JWW, et al. Prevalence of co-morbidity in lung cancer patients and its relationship with treatment: a population-based study. Lung Cancer 1998;21(2):105-13.

[4] Brown JS, et al. Age and the treatment of lung cancer. Thorax 1996;51(6):564-8.

[5] Smith TJ, Penberthy L, Desch CE, Whittemore M, Newschaffer C, Hillner BE, et al. Differences in initial treatment patterns and outcomes of lung cancer in the elderly. Lung Cancer 1995;13(3):235-52.

[6] Charlson M, Pompei P, Ales K. A new method of classigying prognostic comorbidity in longitudinal studies: developments and validation. J Chron Dis 1987;40:37383.

[7] Karnofsky D, Abelman W, Craver L. The use of nitrogen mustard in the palliative treatment of carcinoma with particular reference to bronchogenic carcinoma. Cancer 1948;1.

[8] Zubrod C, Scheniderman M, Frei E. Appraisal of methods for the study of chemotherapy in man: comparative therapeutic trial of nitrogen mustard and triethylenethiophosphoramide. J Chron Dis 1960;11:7-33.

[9] Paesmans M, Sculier JP, Libert P, Bureau G, Dabouis G, Thiriaux $\mathrm{J}$, et al. Prognostic factors for survival in advanced non-small-cell lung cancer: univariate and multivariate analyses including recursive partitioning and amalgamation algorithms in 1052 patients. The European Lung Cancer Working Party. J Clin Oncol Am Soc Clin Oncol 1995;13(5):1221-30.

[10] Sobin LH, Wittekind C. TNM classification of malignant tumours. 5th ed. New York: Wiley-Liss; 1997.
[11] Hermanek P, Sobin LH. TNM Classification of malignant tumours. 4th ed. Berlin: Springer-Verlag; 1987.

[12] Hermanek P, Sobin LH. TNM classification of malignant tumours. 4th, 2nd revision ed. Berlin: Springer-Verlag; 1992.

[13] Study group lung cancer, guideline for diagnostics and treatment for carcinoma of the lung (in Dutch), Limburg IK, Editor, 1997.

[14] Guideline for treatment: non-small cell lung carcinoma. Nijmegen: Comprehensive Cancer Centre East; 1988.

[15] O'Rourke MA, Feussner JR, Feigl P, Laszlo J, et al. Age trends of lung cancer stage at diagnosis, implications for lung cancer screening in the elderly. JAMA 1987;258(7):921-6.

[16] Teeter SM, Holmes FF, McFarlane MJ. Lung carcinoma in the elderly population. Influence of histology on the inverse relationship of stage to age. Cancer 1987;60(6):1331-6.

[17] Montella M, Gridelli C, Crispo A, Scognamiglio F, Ruffolo $\mathrm{P}$, Gatani J, et al. Has lung cancer in the elderly different characteristics at presentation? Oncol Rep 2002;9(5):10936.

[18] van Dijck JA, Festen J, de Kleijn EM, Kramer GW, Tjan Heijnen VC, Verbeek AL, et al. Treatment and survival of patients with non-small cell lung cancer Stage IIIA diagnosed in 1989-1994: a study in the region of the Comprehensive Cancer Centre East, the Netherlands. Lung Cancer 2001;34(1):19-27.

[19] Patterson CJ, Hocking M, Bond M, Teale C, et al. Retrospective study of radiotherapy for lung cancer in patients aged 75 years and over. Age Ageing 1998;27(4):515-8.

[20] Lonardi F, Coeli M, Pavanato G, Adami F, Gioga G, Campostrini $F$, et al. Radiotherapy for non-small cell lung cancer in patients aged 75 and over: safety, effectiveness and possible impact on survival. Lung Cancer 2000;28(1):43-50.

[21] Pignon T, Scalliet $P$, et al. Age has no impact on acute and late toxicity of curative thoracic radiotherapy. Radiother Oncol 1998;46(3):239-48.

[22] Pignon T, Scalliet P. Radiotherapy in the elderly. Eur J Surg Oncol 1998;24(5):407-11.

[23] Olmi P, Ausili Cefaro G. Radiotherapy in the elderly: a multicentric prospective study on 2060 patients referred to 37 Italian radiation therapy centers. Rays 1997;22 (1 Suppl):53-6.

[24] Extermann M. Measuring comorbidity in older cancer patients. Eur J Cancer 2000;36(4):453-71.

[25] Aapro M, Extermann M, Repetto L. Evaluation of the elderly with cancer. Ann Oncol ESMO 2000;11(Suppl 3):223-9.

[26] Firat S, Gore E, Byhardt RW. Do "elderly fit" patients have less comorbidity? Int J Radiat Oncol Biol Phys 2003;55(5):1166-8.

[27] Rocha Lima CM, Herndon JE, Kosty M, Clamon G, Green $M R$, et al. Therapy choices among older patients with lung carcinoma: an evaluation of two trials of the Cancer and Leukemia Group B. Cancer 2002;94(1):181-7.

[28] Chemotherapy in non-small cell lung cancer: a metaanalysis using updated data on individual patients from 52 randomised clinical trials. Non-small Cell Lung Cancer Collaborative Group. BMJ Clin Res 1995;311(7010):899909.

[29] The Elderly Lung Cancer Vinorelbine Italian Study Group. Effects of vinorelbine on quality of life and survival of elderly patients with advanced non-small-cell lung cancer. J Natl Cancer Inst 1999;91(1):66-72.

[30] Limburg IK, editor. Werkgroep-Bronchuscarcinomen, Guideline for diagnostics and treatment for carcinoma of the lung (in Dutch); 2000. 
[31] van Meerbeeck JP. Staging of non-small cell lung cancer: consensus, controversies and challenges. Lung Cancer 2001;34(Suppl 2):S95-107.

[32] Gauden SJ, Tripcony L. The curative treatment by radiation therapy alone of Stage I non-small cell lung can-

cer in a geriatric population. Lung Cancer 2001;32(1): 71-9.

[33] AM T, editor. Treatment for palliation and patient-doctor communication. Houten/diegem: Bohn Stafleu Van Loghum; 1999.

\footnotetext{
Available online at www.sciencedirect.com science $\boldsymbol{d}$ directo
} 